\title{
The establishment of bonds between professional and patient in TB treatment: the performance of primary health care services in a city in the interior of São Paulo ${ }^{1}$
}

\author{
Maria Amélia Zanon Ponce ${ }^{2}$ \\ Silvia Helena Figueiredo Vendramini ${ }^{3}$ \\ Marilene Rocha dos Santos ${ }^{3}$ \\ Maria de Lourdes Sperli Geraldes Santos ${ }^{3}$ \\ Lúcia Marina Scatena ${ }^{4}$ \\ Tereza Cristina Scatena Villa ${ }^{5}$
}

This study evaluated the performance of health care services implementing TB control actions in relation to the establishment of bonds between health professionals and patients in São José do Rio Preto, SP, Brazil from the perspective of patients, health professionals, and managers. A total of 108 patients, 37 health professionals and 15 managers were interviewed through a questionnaire containing 10 indicators of bond-establishment based on the instruments of the Primary Care Assessment Tool, adapted to evaluate tuberculosis control in Brazil. The three groups of actors considered the establishment of bonds satisfactory, though opinions of patients and managers differed in almost all indicators. This fact indicates that the view of managers is still predominantly focused on bureaucratic and administrative aspects, which shows the need for managers to integrate more management and care actions.

Descriptors: Tuberculosis; Professional-Patient Relations; User Embracement; Health Services Evaluation.

\footnotetext{
${ }^{1}$ Supported by Project "Assessment of the performance and organizational dimensions of primary care services in TB control in Urban Areas in Brazil", FAPESP, Process \# 2006/61489-3 and Master's Scholarship, FAPESP, Process \# 2008/52386-1.

${ }^{2}$ RN, Doctoral Student, Escola de Enfermagem de Ribeirão Preto, Universidade de São Paulo, WHO Collaborating Centre for Nursing Research Development, SP, Brazil. E-mail: amelinha_famerp@yahoo.com.br.

${ }^{3}$ RN, Ph.D. in Nursing, Professor, Faculdade de Medicina de São José do Rio Preto, SP, Brazil. E-mail: Silvia - silviahve@gmail.com, Marilene marilene@famerp.br, Maria de Lourdes - mlsperli@gmail.com.

${ }^{4}$ Engineer, Ph.D. in Engineering, Professor, Departamento de Medicina Social, Universidade Federal do Triângulo Mineiro, Uberaba, MG, Brazil. E-mail: Imscatena@uol.com.br.

${ }^{5}$ RN, Ph.D. in Nursing, Full Professor, Escola de Enfermagem de Ribeirão Preto, Universidade de São Paulo, WHO Collaborating Centre for Nursing Research Development, SP, Brazil. E-mail: tite@eerp.usp.br.
}

Corresponding Author:

Tereza Cristina Scatena Villa

Universidade de São Paulo. Escola de Enfermagem de Ribeirão Preto

Departamento Materno-Infantil e Saúde Pública

Av. dos Bandeirantes, 3900

Bairro: Monte Alegre

CEP: 14040-902, Ribeirão Preto, SP, Brasi

E-mail: tite@eerp.usp.br 


\section{Vínculo profissional/doente no tratamento da tuberculose: desempenho da atenção básica em município do interior paulista}

O objetivo do estudo foi avaliar o desempenho dos serviços de saúde que realizam ações de controle da tuberculose (TB), relacionado ao vínculo entre o profissional e o doente, no município de São José do Rio Preto, SP, na percepção de doentes, profissionais de saúde e gestores. Foram entrevistados 108 doentes, 37 profissionais e 15 gestores, utilizando questionário elaborado com 10 indicadores para a dimensão vínculo, construídos com base no Primary Care Assessment Tool, adaptado para avaliar a atenção à tuberculose no Brasil. O vínculo foi avaliado como satisfatório pelos três atores, entretanto, houve variabilidade entre as opiniões dos doentes e os gestores em quase todos os indicadores, o que permite inferir que a visão dos gestores ainda é voltada predominantemente aos aspectos burocráticos e administrativos, necessitando que esses integrem mais as ações gerenciais e assistenciais.

Descritores: Tuberculose; Relações Profissional-Paciente; Acolhimento; Avaliação de Serviços de Saúde.

\section{Vínculo entre profesional y enfermo en el tratamiento de la tuberculosis: desempeño de la atención básica en un municipio del estado de Sao Paulo}

El objetivo del estudio fue evaluar el desempeño de los servicios de salud que realizan acciones de control de la TB relacionado al vínculo entre el profesional y el enfermo, en el municipio de Sao José del Rio Preto, en Sao Paulo, en la percepción de enfermos, profesionales de la salud y gestores. Fueron entrevistados 108 enfermos, 37 profesionales y 15 gestores utilizando un cuestionario elaborado con 10 indicadores para la dimensión vínculo construidos con base en el Primary Care Asesment Tool, adaptado para evaluar de la atención a la tuberculosis en Brasil. El vínculo fue evaluado como satisfactorio por los tres actores, entre tanto hubo variabilidad entre las opiniones de los enfermos y los gestores en casi todos los indicadores, lo que permite inferir que la visión de los gestores todavía está orientada predominantemente por los aspectos burocrático/administrativos, necesitando que estos integren más las acciones gerenciales y asistenciales.

Descriptores: Tuberculosis; Relaciones Profesional-Paciente; Acogimiento; Evaluación de Servicios de Salud.

\section{Introduction}

The solvability of actions in the control of Tuberculosis (TB) suffers from the influence of factors associated with the behavior of patients, the modality of the treatment employed and the operation of services, with an emphasis on the work of health professionals $^{(1)}$.

The work organization of the health team is determinant in the success of TB control, especially in relation to treatment adherence ${ }^{(1)}$. From this perspective, strategies to control the disease based not only on new diagnostic or therapeutic methods but also on the incorporation of relationship technologies that emphasize reception/welcoming processes, the establishment of bonds and integral care as managers of care actions ${ }^{(2)}$, have been discussed in recent years.

The reception and establishment of bonds represent operational guidelines to reach integrality in health, considering that bonds establish strong interpersonal ties between health professionals and patients through relationships where there is listening, dialog, respect and humanization of care, promoting the co-responsabilization of health ${ }^{(1,3)}$. 
The interest and responsabilization of professionals in relation to the health needs of patients arouses feelings of safety and trust in users and leads them to more frequently seek the service in which they feel welcomed and have established bonds, which facilitates $\operatorname{access}^{(4)}$.

The establishment of bonds among the subjects seeks to encourage self-care, conferring autonomy on patients and allowing then to participate in the decisionmaking process concerning the health condition they want to achieve ${ }^{(5)}$. Hence, the treatment is shared, which strengthens the relationship of trust between patient and professional, favoring treatment adherence and reaching a cure ${ }^{(6)}$.

This paper is the result of the multicenter project "Evaluation of organizational dimensions and performance of primary care services in TB control at urban centers in different regions of Brazil". The performance of health services implementing TB control actions related to the bonds established between professionals and patients in São José do Rio Preto, SP, Brazil is evaluated from the perceptions of the patients, health professionals and managers.

\section{Methods}

This quantitative and evaluative study was conducted in São José do Rio Preto, SP, Brazil, one of the main cities in the state of São Paulo for the control of TB.

In 2007, the study's period, TB care provided in this city had as its main framework a centralized program and management with scheduled actions of diagnosis and treatment performed by the specialized team in the Tuberculosis Control Program (TCP). However, some actions such as supervised dosages of medication were in a gradual process of decentralization, becoming the responsibility of primary health care units (Primary Health Care Units and Family Health Units). Given this process, it was possible to find patients being monitored in two types of services: they were cared for by the TCP team and also received Supervised Treatment (ST) from the teams of the primary care units in their scope areas.

\section{Study population}

Three sets of actors participated in this study: TB patients, health professionals and managers. A total of 108 (69.2\%) TB patients out of 156 diagnosed in 2007 were interviewed, with the following inclusion criteria: being older than 18 years of age, residing in São José do Rio Preto, SP, Brazil and being under treatment for at least one month during the data collection period.

A total of 37 health professionals (physicians, nurses, nursing auxiliaries and technicians) working for the TCP $(100 \%)$ and in primary health care units $(27 \%)$ providing ST during the data collection period were interviewed. Fifteen managers (100\%) working as area coordinators at the central level and managers of the TCP and of primary health care units providing TS during the data collection period also participated in the study.

\section{Data collection}

Data were collected from June to July 2007 through interviews. A structured questionnaire based on the instruments composed of the Primary Care Assessment Tool and adapted for the TB control actions implemented in Brazil was applied to each set of $\operatorname{actors}^{(7)}$.

The instruments contained questions concerning the dimensions of Primary Health Care, while in this study, those concerning the dimension 'establishment of bonds' were used. Considering the specificity of actors, the questionnaire directed to the patients included information on gender, schooling, place where the medical consultation and ST were provided. For the professionals and managers, the questionnaire included questions about their work place (type of work), profession and function.

Ten indicators were considered to evaluate the dimension 'bonding' presented in Tables 1 and Figure 2.

The interviewees answered each question according to varied classification scales: dichotomous; multiple choice with a single correct answer; and a Likert scale, that provides pre-established answers. A score from zero to five was attributed to each answer, while zero was used for answers do not know or do not apply and the values from one to five to the degree of agreement with statements.

Each indicator corresponded to the sum of answers of all the interviewees divided by the total number of interviews to obtain an average value. A composite index was developed for each group of interviewees. This index corresponds to the average value of answers obtained in each group and represents the performance of the dimension 'bonding' from the perceptions of patients, professionals and managers.

The indicators were individually analyzed and compared among the three sets of actors. Data were submitted to variance analysis (ANOVA) with the use of the $F$ test and multiple comparisons among 
averages were performed through the Tukey test. For the analyses that violated ANOVA criteria, the nonparametric Kruskall-Wallis ( $\mathrm{H}$ test) was used and the test for multiple comparisons between averages, the Dunn test, was used. The level of statistical significance adopted in all the tests was fixed at $5 \%$.

The performance of each indicator and composite index of the dimension 'bonding' was classified as unfavorable for average values close to 1 and 2, values close to 3 were classified as regular, and values close to 4 and 5 as favorable.

The project was approved by the Research Ethics Committee at the University of São Paulo at Ribeirão Preto, College of Nursing (Protocol no 0762/2007). Confidentiality was ensured to all the individuals providing information and the participants signed free and informed consent forms.

\section{Results}

Most of the interviewed patients were male $(65.7 \%) ; 39.8 \%$ had not completed primary school; only $12 \%$ completed secondary school. In regard to health professionals, $27.1 \%$ were physicians; $32.4 \%$ nurses; $10.8 \%$ nursing technicians; and $29.7 \%$ nursing auxiliaries. Most of the interviewed nursing professionals $(62.1 \%)$ worked in the primary health care units that had patients under treatment during the data collection period and $37.9 \%$ worked in the TCP.
Eight $(53.3 \%)$ of the 15 interviewed managers were technical managers: two coordinators of programs (TCP and AIDS), four coordinators in the technical area of Primary Care and the Family Health Strategy, one coordinator of the division of health centers, and one coordinator of Epidemiological Surveillance. The remaining seven $(46.7 \%)$ were care managers of the TCP and of primary health care units.

Most $(82.4 \%)$ of the routine medical consultations to monitor TB patients were performed in the referral outpatient unit with the TCP specialized team. ST was provided to $83.3 \%(n=90)$ of the patients, while $42.6 \%$ $(n=46)$ of these received the supervised dosage by the primary health care units, $14.8 \%(n=16)$ in the TPC, and $25.9 \%(n=28)$ at home, mainly monitored by the TCP.

Table 1 presents the average, standard deviation and the $F$ test value and also the value of the nonparametric Kruskall-Wallis test ( $H$ test) for the 10 indicators of 'bonding' and the composite index analyzed according to the three categories of interviewees. The composite index indicates that TB patients (4.79), health professionals (4.70) and managers (4.16) evaluated the performance of this dimension satisfactorily.

Figure 1 presents the results of the multiple comparison tests (Tukey test and Dunn test) among the indicators of the three groups.

Table 1 - Indicators of 'bonding' from the perception of patients, health professionals, and managers. São José do Rio Preto, SP, Brazil, 2007

\begin{tabular}{|c|c|c|c|c|c|c|c|}
\hline \multirow[t]{2}{*}{ Indicators } & \multicolumn{2}{|c|}{$\begin{array}{l}\text { Patients } \\
(n=108)\end{array}$} & \multicolumn{2}{|c|}{$\begin{array}{l}\text { Professionals } \\
\qquad(n=37)\end{array}$} & \multicolumn{2}{|c|}{$\begin{array}{l}\text { Managers } \\
\qquad(n=15)\end{array}$} & \multirow[t]{2}{*}{ F or H TEST } \\
\hline & $\bar{x}$ & sd & $\bar{x}$ & sd & $\bar{x}$ & sd & \\
\hline Consultations with the same health professional ${ }^{*}$ & 4.83 & 0.48 & 4.78 & 0.47 & 4.33 & 1.04 & $0.0058^{\dagger}$ \\
\hline Clarification of doubts concerning treatment ${ }^{*}$ & 4.92 & 0.35 & 4.78 & 0.46 & 4.50 & 0.65 & $<0.0001^{\dagger}$ \\
\hline Comprehension of doubts presented by TB patients ${ }^{\ddagger}$ & 4.87 & 0.52 & 4.75 & 0.49 & 4.13 & 0.74 & $<0.0001^{\dagger}$ \\
\hline Concern of professionals with patients' other health problems ${ }^{\ddagger}$ & 4.42 & 1.27 & 4.62 & 0.68 & 3.86 & 1.06 & $0.0008^{\dagger}$ \\
\hline Time reserved for patients to express their doubts and concerns ${ }^{\ddagger}$ & 4.92 & 0.35 & 4.81 & 0.46 & 4.46 & 0.63 & $<0.0001^{\dagger}$ \\
\hline Clarity in responding to doubts presented by TB patients ${ }^{\ddagger}$ & 4.86 & 0.58 & 4.78 & 0.41 & 4.06 & 1.03 & $<0.0001^{\dagger}$ \\
\hline Recording the complaints of patients in their files ${ }^{\ddagger}$ & 4.96 & 0.38 & 4.78 & 0.71 & 4.13 & 0.83 & $<0.0001^{\dagger}$ \\
\hline Explanation concerning the medication used for the TB treatment ${ }^{\neq}$ & 4.89 & 0.51 & 4.97 & 0.16 & 4.60 & 1.05 & $0.0387^{\dagger}$ \\
\hline $\begin{array}{l}\text { Request for information concerning medication used by the TB } \\
\text { patients* }\end{array}$ & 4.68 & 0.94 & 4.45 & 0.98 & 4.20 & 1.01 & 0.1497 \\
\hline Evaluation of patients concerning care provided by the health team* & 4.61 & 0.59 & 4.40 & 0.59 & 3.86 & 0.99 & $0.0001^{\dagger}$ \\
\hline Composite index of the dimension 'bonding' & 4.79 & 0.70 & 4.70 & 0.61 & 4.16 & 0.96 & $<0.0001^{\dagger}$ \\
\hline
\end{tabular}

$\bar{x}=$ average

$\mathrm{SD}=$ standard deviation

*F test (ANOVA)

${ }^{\dagger}=\mathrm{p}<0.05$

${ }^{\ddagger}$ non-parametric ANOVA, Kruskall-Wallis (H test) 


\begin{tabular}{|c|c|}
\hline Indicators & $\begin{array}{l}\text { Result of the multiple } \\
\text { comparison test }\end{array}$ \\
\hline \multirow{3}{*}{$\begin{array}{l}\text { Consultation with the same health } \\
\text { professional }\end{array}$} & $\mathrm{TB}=\mathrm{P}$ \\
\hline & $\mathrm{TB} \neq \mathrm{M}^{*}$ \\
\hline & $P=M$ \\
\hline \multirow{3}{*}{$\begin{array}{l}\text { Clarification of doubts concerning the } \\
\text { treatment by the health professional }\end{array}$} & $\mathrm{TB}=\mathrm{P}$ \\
\hline & $\mathrm{TB} \neq \mathrm{M}^{+}$ \\
\hline & $P=M$ \\
\hline \multirow{3}{*}{$\begin{array}{l}\text { Comprehension of doubts presented by TB } \\
\text { patients to the health professional }\end{array}$} & $\mathrm{TB}=\mathrm{P}$ \\
\hline & $\mathrm{TB} \neq \mathrm{M}^{+}$ \\
\hline & $P \neq M$ \\
\hline \multirow{3}{*}{$\begin{array}{l}\text { Concern of professionals with patients' other } \\
\text { health problems }\end{array}$} & $\mathrm{TB}=\mathrm{P}$ \\
\hline & $\mathrm{TB} \neq \mathrm{M}^{+}$ \\
\hline & $P=M$ \\
\hline \multirow{3}{*}{$\begin{array}{l}\text { Time reserved for patients to express their } \\
\text { doubts and concerns }\end{array}$} & $\mathrm{TB}=\mathrm{P}$ \\
\hline & $\mathrm{TB} \neq \mathrm{M}^{+}$ \\
\hline & $P=M$ \\
\hline \multirow{3}{*}{$\begin{array}{l}\text { Clarity in responding to doubts presented by } \\
\text { TB patients }\end{array}$} & $\mathrm{TB}=\mathrm{P}$ \\
\hline & $\mathrm{TB} \neq \mathrm{M}^{+}$ \\
\hline & $P \neq M$ \\
\hline \multirow{3}{*}{$\begin{array}{l}\text { Health professionals record the complaints } \\
\text { of patients in their files }\end{array}$} & $\mathrm{TB}=\mathrm{P}$ \\
\hline & $\mathrm{TB} \neq \mathrm{M}^{+}$ \\
\hline & $P \neq M$ \\
\hline \multirow{3}{*}{$\begin{array}{l}\text { Explanation concerning the medication used } \\
\text { for TB treatment }\end{array}$} & $\mathrm{TB}=\mathrm{P}$ \\
\hline & $\mathrm{TB}=\mathrm{M}^{+}$ \\
\hline & $P=M$ \\
\hline \multirow{3}{*}{$\begin{array}{l}\text { Request for information concerning } \\
\text { medication used by the TB patients }\end{array}$} & $\mathrm{TB}=\mathrm{P}$ \\
\hline & $\mathrm{TB}=\mathrm{M}^{*}$ \\
\hline & $P=M$ \\
\hline \multirow{3}{*}{$\begin{array}{l}\text { Evaluation of patients concerning the care } \\
\text { provided by the health team }\end{array}$} & $\mathrm{TB}=\mathrm{P}$ \\
\hline & $\mathrm{TB} \neq \mathrm{M}^{*}$ \\
\hline & $P=M$ \\
\hline
\end{tabular}

$*:$ Tukey; $+:$ Dunn

Legend: $\mathrm{TB}=$ Patients; $\mathrm{P}=$ Professionals; $\mathrm{M}=$ Managers

Figure 1 - Comparison among the indicators of bonding from the perception of patients, health professionals and managers. São José do Rio Preto, SP, Brazil, 2007

The indicators Explanation concerning the medication used for the TB treatment and Request for information concerning medication used by the TB patients were similar among the three groups of actors.

The patients and managers differ in the indicators Consultation with the same health professional, Clarification of doubts concerning the treatment by the health professionals, Concern of professionals with patients' other health problems, Time reserved for patients to express their doubts or concerns and in the indicator Evaluation of patients concerning care provided by the health team.
Patients and professionals presented statistically similar averages, while managers differ from both, in regard to the indicators Comprehension of doubts presented by TB patients to the health professional, Clarity in responding to doubts presented by TB patients and Health professionals record the complaints of patients in the files.

\section{Discussion}

The results concerning the characteristics of the interviewed patients, most of whom were male and with a low level of schooling, are in agreement with the profile of TB patients found in the city in a historical series of 10 years $^{(8)}$ and of other cities in Brazil(9-10), which can be an important factor of vulnerability to TB and a determinant of low treatment adherence(11).

In relation to the place where care is provided, most of the TB patients attended medical treatment (monthly medical consultation of follow-up) with the TCP team while the supervised dosage was mainly provided in primary health care units. This information concurs with the way TB care was organized at the time of data collection (centralized in the TCP with some actions being gradually decentralized to sphere of the health units) and reinforces the fact that most of the TB patients were simultaneously monitored by health services with differ logics of care delivery: in traditional services, which are guided by the organization of care by programs and focus their work on certain diseases and risks or in specific populations; and in primary health care units guided by the organization of care with a focus on the clients' ascription, territory, diagnostic process of health situation, and planning based on the local context and diseases in general.

A study conducted in priority cities in the state of São Paulo in 2005 showed that there is a tendency to decentralize activities of a technical nature (delivery of medication, observation of medication provided through the ST and the search for individuals with respiratory symptoms) to the primary health care units while managerial activities (management of information systems, monitoring of the TB situation based on an information system, planning and execution of training/ qualifications, supervision of local health teams) are conducted by the city coordination of the TCP and are centralized(12)

ST coverage among patients in the study is considered high $(83.3 \%)$ and even though efforts are still necessary to achieve the goals recommended by 
the World Health Organization (100\%), the ST rate has grown since its implementation in the city in 1998. In 2002, the ST coverage among non-TB/HIV co-infected individuals was below $20 \%$ but reached $59 \%$ in that same year(13).

In regard to the established bonds, the obtained results analysis showed that TB patients are cared for by the same professional, who reserves sufficient time for them to express their concerns and always understands and answers with clarity when doubts are presented.

The fact that the patients are cared for by the same professional indicates there is an affinity between patients and professionals, hence patients have a reference for health care delivery. A similar result was found in Fortaleza, CE, Brazil, which indicated there is a greater establishment of bonds when professionals know the patients and are known by the patients who look for them when facing a new event or to express their doubts ${ }^{(14)}$.

The periodical follow-up of patients by a professional of reference, in addition to facilitating an interpersonal relationship, also favors the participation of patients during the treatment. It also encourages the evaluation of the development of problems found in previous consultations and professionals consequently are able to provide more efficient care(3).

A study carried out in Ubatuba, SP, Brazil verified that health professionals who always cared for patients during return visits were able to identify those at risk of abandoning their treatment and, consequently, pay special attention to them(15).

Because TB is a chronic disease and still has a stigmatizing character, its prolonged treatment can affect the lives of patients and interfere in their physical, social, psychological, economic and spiritual dimensions. Hence, it is extremely important that health professionals are sensitive and develop active listening skills and provide sufficient time for patients to talk about their anxieties and doubts ${ }^{(16)}$. When there is active listening and greater affinity occurs between these two actors, the patient develops trust in the professional and in the health service and feels safe enough to reveal his/her concerns $^{(4,14)}$.

This study revealed that health professionals talks to the TB patients about other health problems in addition to the disease per se, which allows the professional to see the patient in a holistic manner, heed his/her other needs $^{(3)}$ and identify concepts internalized by the patient throughout life and that may interfere in his/her conduct toward the disease ${ }^{(17)}$.
A broader communication based not solely on the disease's biological aspects also contributes to therapeutic success as demonstrated in a study conducted in Nepal where care delivered focused only on aspects such as medication, side effects, and duration of treatment led to an increased risk of non-adherence ${ }^{(18)}$.

These indicators may be compromised by the existence of barriers, such as a quantitative and qualitative deficiency of human resources, a centralized and fragmented view of TB control actions in the health system worsened by the high turnover of professionals in the health service, especially in primary health care, which is in part a consequence of political party discontinuity. These factors result in an overload of functions and affect the interaction between professionals and patients ${ }^{(14,19)}$.

The city in this study does not differ from the scenario presented earlier. The studied city also presents some barriers that can potentially interfere in the establishment of bonds. However, it is believed that the high frequency with which care is provided by the same professional, the time made available to patients, and the favorable evaluation concerning listening and communication can be explained by the fact that most of the patients are monitored by the same TCP team, since care in this health service is exclusively directed to TB patients.

The study also revealed the concern on the part of professionals over issues presented by the patients. Professionals explain about TB medication and allow patients to clarify their doubts in relation to the medication routinely used.

These results are extremely important to treatment adherence, since treatment is successful when patients acknowledge their role as being co-responsible for their own health. For that, patients should have knowledge of all aspects related to care, including the medication therapy ${ }^{(16)}$. They should also participate jointly with the group of technicians responsible for their care in decisions concerning their health and needs in an interrelated, competent and resolutive manner, not only based on the logic of curative medical care ${ }^{(20)}$.

The complaints presented by the patients are recorded in the patients' files and this is an important action to proceed with care. However, it is necessary to evaluate the quality of these notes since medical files will only serve as instruments providing continuity of care if they contain important information concerning the patients in a objective and complete way that enables access to content generated in all the previous consultations $^{(3)}$. 
The care delivered by the health team to the TB patient during his/her treatment was well-evaluated by the three groups of participants. The positive results concerning this evaluation of the health team are probably related to the results of other indicators presented earlier, because these expressed a high level of satisfaction in relation to the dimension 'bonding' in all the attributes: respect, consideration, active listening, comprehension, and welcome provided by the team.

Even though the care delivered by the health team was well-evaluated, the professionals and managers attributed scores lower than those of patients. This fact may be explained by the different perceptions and expectations among the three groups of actors in relation to the delivered care. Patients evaluated the care provided by the team while valuing the way they are welcomed by the health service professionals and by the possibility of having their more immediate individual needs met. Professionals and managers evaluated the delivered care based on results, from the perspective of providing care focused on the individual and the collective, which jointly show the performance of actions developed by the team through effects and impact (indicators) on the health of the cared population(17).

Finally, the dimension 'bonding' presented satisfactory performance in the studied city according to the actors participating in the study: patients attributed the highest scores to this dimension in most of the indicators.

One of the factors that might have contributed to a better evaluation on the part of patients is the fact that most were monitored by the TCP team, which cares for a smaller number of users (only TB patients) and because they were under ST at the time of data collection. Studies indicate that if a large number of patients is cared for, then there is a less favorable influence on the communication and relationships established between patients and health professionals $^{(10)}$. At the same time, treatment supervision activities enable the establishment of bonds, since these require professionals to contextualize care to the social surroundings in which individuals are inserted, achieved through close relationships of trust between patients and professionals, broadening this interaction (21-22).

Managerson the otherhand, despitetheir satisfactory evaluation, presented lower scores, which differ in most of the indicators from those of patients. This result is in line with a study carried out in Ribeirão Preto, SP, Brazil, which indicates that local managers are increasingly assuming bureaucratic and administrative activities, in addition to technical issues. These professionals point out that their routine consists of work supervision and the control of actions, while planning and evaluation of professionals and health practices of the units are left to a second plan, dissociating management from care delivery. This posture often leads to managers and the users of service becoming distant, even if professionals work as care managers ${ }^{(23)}$.

\section{Conclusion}

This study revealed that TB patients being cared for in São José do Rio Preto, SP, Brazil are frequently monitored by the same professional and there is efficient communication with a focus on patient subjectivity and the supply of information concerning the therapeutic scheme. These are some of the aspects that favor the establishment of bonds between patients and health professionals who perform TB control actions.

Three groups of actors favorably evaluated the dimension 'bonding' in the city, though managers attributed lower scores, which is contrary to patients' scores in most of the indicators. In this context, the view of managers is still predominantly focused on bureaucratic and administrative aspects; they need to integrate more managerial and care actions.

Therefore, a management with greater political involvement is needed as well as more integration with patients and health professionals to attain planning and organizational knowledge in order to obtain tools that enable the appropriate development of actions to control TB

\section{References}

1. Sá LD, Souza KMJ, Nunes MG, Palha PF, Nogueira JA, Villa TCS. Tratamento da tuberculose em unidades de saúde da família: histórias de abandono. Texto Contexto Enferm. outubro-dezembro 2007;16(4):712-8.

2. Coelho MO, Jorge MSB. Tecnologia das relações como dispositivo do atendimento humanizado na atenção básica á saúde na perspectiva do acesso, do acolhimento e do vínculo. Ciênc Saúde Colet. 2009;14(Supl 1):1523-31.

3. Starfield B. Atenção Primária: equilíbrio entre necessidades de saúde, serviços e tecnologia. Brasília: Ministério da Saúde /UNESCO; 2002. 725 p.

4. Ramos DD, Lima, MADS. Acesso e acolhimento em uma unidade de saúde de Porto Alegre, Rio Grande do Sul, Brasil. Cad Saúde Pública. 2003;19(1):27-34.

5. Lima MADS, Ramos DD, Rosa RB, Nauderer TM, Davis R. Acesso e acolhimento em unidades de saúde na visão dos usuários. Acta Paul Enferm. 2007;20(1):7-12. 
6. Jaiswal A, Singh V, Ogden JA, Porter JD, Sharma PP, Sarin $\mathrm{R}$, et al. Adherence to tuberculosis treatment: lessons form the urban setting of Delhi, India. Trop Med Int Health. 2003;8(7):625-33.

7. Villa TCS, Ruffino-Netto A. Questionário para avaliação de desempenho de serviços de atenção básica no controle da tuberculose no Brasil. J Bras Pneumol. 2009;35(6):610-2.

8. Vendramini SHF, Santos MLSG, Gazetta CE, Chiaravalotti-Neto F, Ruffino-Netto A, Villa, TCS. Tuberculosis risk and socio-economic level: a study of a city in the Brazilian south-east, 1998-2004. Int J Tuberc Lung Dis. 2006;10(11):1231-5.

9. Lindoso AABP, Waldman EA, Komatsu NK, Figueiredo SM, Taniguchi M, Rodrigues LC. Perfil de pacientes que evoluem para óbito por tuberculose no município de São Paulo, 2002. Rev Saúde Pública. 2008;42(5):805-12.

10. Brunello MEF, Cerqueira DF, Pinto IC, Arcêncio RA, Cardozo-Gonzales RI, Villa TCS, et al. Patient-Health professional bonding in the Tuberculosis care. Acta Paul Enferm. 2009;22(2):176-82.

11. Santos MLSG, Vendramini SHF, Gazetta CE, Oliveira SAC, Villa TCS. Poverty: socioeconomic caracterization at tuberculosis. Rev. Latino-Am. Enfermagem. 2007;15(esp): 762-7.

12. Villa TCS, Ruffino-Netto A, Arcêncio RA, CardozoGanzales RI. As políticas de controle da tuberculose no Sistema de Saúde no Brasil e a implantação da estratégia DOTS (1980-2005). In: Villa TCS, Ruffino Netto A, organizadores. Tuberculose: implantação do DOTS em algumas regiões do Brasil: histórico e peculiaridades regionais. Ribeirão Preto: FMRP/USP; 2006. p. 29-47.

13. Vendramini SHF, Gazetta CE, Chiaravalloti-Neto F, Cury MRCO, Meirelles EB, Kuyumjian FG, et al. Tuberculose em município de porte médio do sudeste do Brasil: indicadores de morbidade e mortalidade, de 1985 a 2003. J Bras Pneumol. 2005;31(3):237-3.

14. Monteiro MM, Figueiredo VP, Machado MFAS. Formação do vínculo na implantação do Programa Saúde da Família numa Unidade Básica de Saúde. Rev Esc Enferm USP. 2009;43(2): 358-64.

15. Bergel FS, Gouveia N. Retornos freqüentes como nova estratégia para adesão ao tratamento da tuberculose. Rev Saúde Publica. 2005;39(6):898-905.

16. Paz EPA, Sá AMM. The daily routine of patients in tuberculosis treatment in basic health care units: a phenomenological approach. Rev. Latino-Am. Enfermagem. 2009;17(2):180-6.

17. Archanjo DR, Archanjo LR, Silva LL, organizadores. Saúde na Família na Atenção básica. Curitiba: Ibpex; 2007.
18. Mishra P, Hansen EH, Sabroe S, Kafle KK. Socioeconomic status and adherence to tuberculosis treatment: a case-control study in a district of Nepal. Int J Tuberc Lung Dis. 2005;9(10):1134-9.

19. Monroe AA, Cardoso-Gonzales RI, Palha PF, Sassaki CM, Ruffino-Netto A, Vendramini SHF, et al. O envolvimento de equipes de atenção básica à saúde no controle da tuberculose. Rev Esc Enferm USP. 2008;42(2):262-7.

20. Mendes EV. Os grandes dilemas do SUS. Salvador: Casa da Qualidade; 2001.

21. Gomes ALC, Sá LD. As concepções de vínculo e a relação com a tuberculose. Rev Esc Enferm USP 2009;43(2):365-72.

22. Villa TCS, Assis EG, Oliveira MF, Arcêncio RA, CardozoGonzales RI, Palha PF. Cobertura do tratamento diretamente observado (DOTS) no Estado de São Paulo (1998 a 2004). Rev Esc Enferm USP. 2008;42(1):98-104.

23. Protti ST, Silva LMC, Palha PF, Villa TCS, Ruffino Netto A, Nogueira JÁ, Sá LD. A gerência da unidade básica de saúde no controle da tuberculose: um campo de desafios. Rev Esc Enferm USP. In press 2010.
Received: Feb. 22nd 2010

Accepted: Oct. $4^{\text {th }} 2010$ 